\title{
Role and targeting of anaplastic lymphoma kinase in cancer
}

\author{
Carminia Maria Della Corte, Giuseppe Viscardi, Raimondo Di Liello, Morena Fasano, Erika Martinelli, Teresa Troiani, \\ Fortunato Ciardiello and Floriana Morgillo ${ }^{*}$ (D)
}

\begin{abstract}
Anaplastic lymphoma kinase (ALK) gene activation is involved in the carcinogenesis process of several human cancers such as anaplastic large cell lymphoma, lung cancer, inflammatory myofibroblastic tumors and neuroblastoma, as a consequence of fusion with other oncogenes (NPM, EML4, TIM, etc) or gene amplification, mutation or protein overexpression.

ALK is a transmembrane tyrosine kinase receptor that, upon ligand binding to its extracellular domain, undergoes dimerization and subsequent autophosphorylation of the intracellular kinase domain. When activated in cancer it represents a target for specific inhibitors, such as crizotinib, ceritinib, alectinib etc. which use has demonstrated significant effectiveness in ALK-positive patients, in particular ALK-positive non- small cell lung cancer. Several mechanisms of resistance to these inhibitors have been described and new strategies are underway to overcome the limitations of current ALK inhibitors.
\end{abstract}

Keywords: ALK, Crizotinib, Alectinib, Ceritinib, Tyrosine kinase inhibitor, Resistance

\section{Background}

Anaplastic lymphoma kinase (ALK) is a receptor tyrosine kinase belonging to the insulin receptor superfamily sharing a high degree of homology with leukocyte tyrosine kinase (LTK) [1]. The human ALK gene is located on the $2 \mathrm{p} 23$ chromosomal segment and encodes for a polypeptid of 1620 amino acid which undergoes to post-translational modifications generating a mature ALK protein of approximately $200-220 \mathrm{kDa}[2,3]$. The ALK mature protein is a classical receptor tyrosine kinase that comprises an extracellular ligand-binding domain of 1030 aminoacids (aa), a transmembrane domain (28 aa), and an intracellular tyrosine kinase domain (561 aa) [4]. The kinase domain shares with the other kinases of the same family the 3-tyrosine motif (Tyr1278, Tyr1282 and Tyr1283) which is located in the activation loop and represent the major auto-phosphorylation site of kinase activity [5, 6] (Fig. 1). ALK becomes activated only upon ligand-induced homo-dimerization, and inactivated through de-phosphorylation by receptor protein tyrosine phosphatase beta and zeta complex

\footnotetext{
* Correspondence: floriana.morgillo@unicampania.it

Medical Oncology, Department of Experimental and Internal Medicine " $F$

Magrassi", University of Campania "Luigi Vanvitelli", via S. Pansini 5, 80131

Naples, Italy
}

(c) The Author(s). 2018 Open Access This article is distributed under the terms of the Creative Commons Attribution 4.0 International License (http://creativecommons.org/licenses/by/4.0/), which permits unrestricted use, distribution, and reproduction in any medium, provided you give appropriate credit to the original author(s) and the source, provide a link to the Creative Commons license, and indicate if changes were made. The Creative Commons Public Domain Dedication waiver (http://creativecommons.org/publicdomain/zero/1.0/) applies to the data made available in this article, unless otherwise stated. Two proteins, midkine and pleiotrophin, have been reported to be activating ligands for mammalian ALK [8], although they are not specific for ALK [9].

ALK activates multiple pathways, including phospholipase $\mathrm{C} \gamma$, Janus kinase (JAK)-signal transducer and activator of transcription (STAT), Phosphoinositide 3-kinase (PI3K)-AKT, mammalian target of rapamycin (mTOR), sonic hedgehog, JUNB, CRKL-C3G (also known as RAPGEF1)-RAP1 GTPase and mitogen-activated protein kinase (MAPK) signaling cascades, which affect cell growth, transformation and anti-apoptotic signaling [9] (Fig. 2).

ALK is highly conserved across species. ALK mRNA expression is present [10] in the adult human brain, where it is thought to play a role in the development and function of the nervous system, and it is also expressed in small intestine, testis, prostate, and colon whereas human lymphoid tissues and cells, lung and other organs are excluded.

The first identification of ALK occurred in anaplastic large cell lymphoma (ALCL) as the product of a gene rearrangement $[10,11]$. Since then, $A L K$ rearrangement, mutations, or amplification was discovered in a series of 


\section{ALK protein structure}

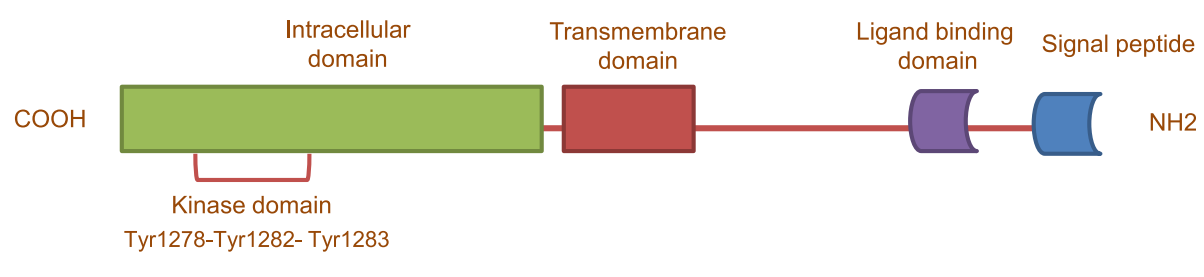

\begin{tabular}{ccccccccc}
1620 & 1392 & 1116 & 1057 & 1031 & 401 & 391 & 26 & 1 \\
\hline & $\mid$ & $\mid$ & $\mid$ & $\mid$ & $\mid$ & $\mid$
\end{tabular}

1620 aа

Fig. 1 Structure of ALK protein. The human ALK protein is a polypeptid of 1620 amino acid. The ALK mature protein is a classical receptor tyrosine kinase that comprises an extracellular ligand-binding domain, a transmembrane domain, and an intracellular tyrosine kinase domain which harbors the 3-tyrosine motif (Tyr1278, Tyr1282 and Tyr1283) which represents the major auto-phosphorylation site regulating kinase activity

tumors including lymphoma, neuroblastoma, and nonsmall cell lung cancer (NSCLC) [12].

So far, 21 different genes have been described as being translocated with $A L K$ and, in addition to this complexity, within the different $A L K$ fusion there are several breakpoint variants. Different $A L K$ fusion proteins may be responsible for different proliferation rates, colony formation, invasion and tumorigenicity capabilities, leading to activation of various signaling pathways.

The $70-80 \%$ of all ALK-positive ALCL patients present the $A L K$ gene (2p23) and the NPM (nucleolar phosphoprotein B23, numatrin) gene (5q35) translocation [13]

\section{ALK signaling pathway}

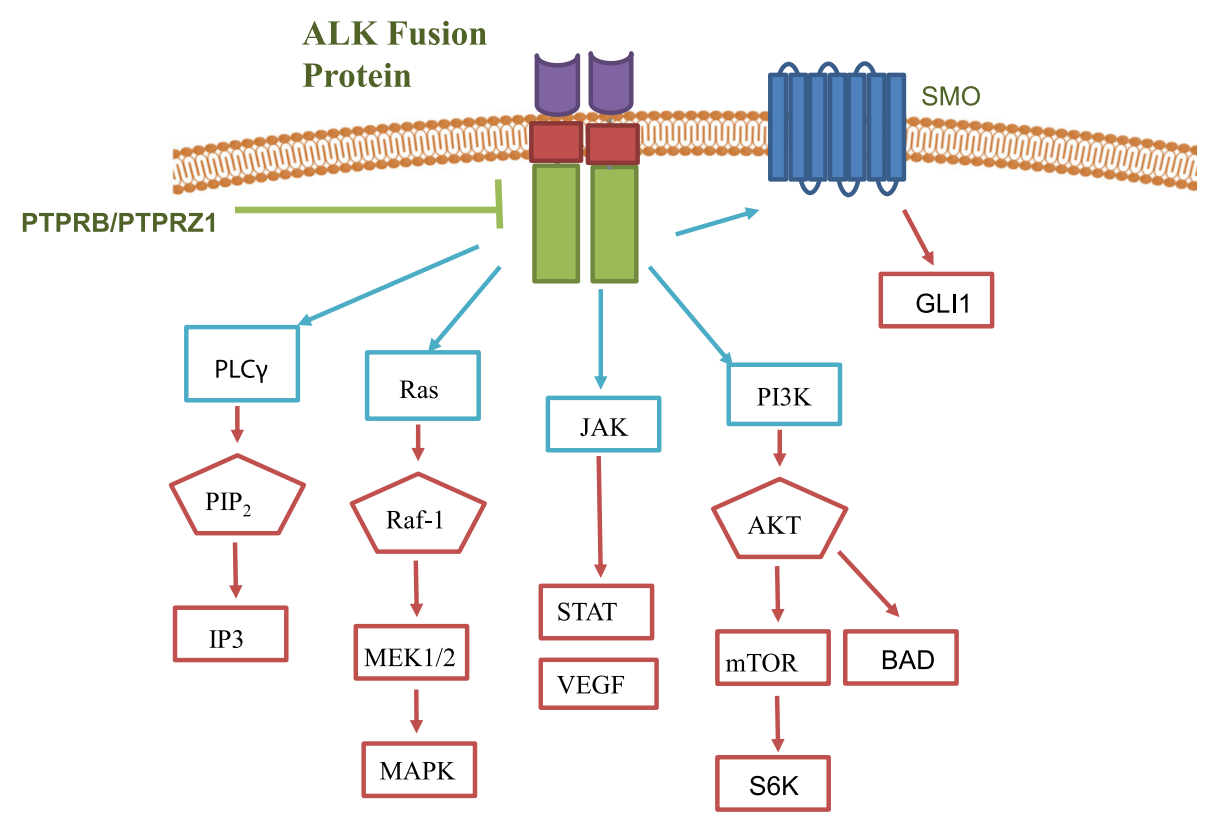

Cell proliferation, invasion, migration, inhibition of apoptosis, angiogenesis

Fig. 2 ALK signaling pathway. ALK activates multiple pathways, including phospholipase $C$ y, Janus kinase (JAK)-signal transducer and activator of transcription (STAT), PIBK-AKT, mTOR, sonic hedgehog (SMO and GLI), and MAPK signaling cascades, which affect cell growth, transformation and anti-apoptotic signaling. Receptor protein tyrosine phosphatase beta and zeta complex (PTPRB/PTPRZ1) inactivates ALK through de-phosphorylation 
with several $t(2 ; 5)$ breakpoint variants described. NPM (also known as NPM1), encodes for a protein which is involved in the regulation of cell division, DNA repair, transcription and genomic stability [14]. The NPM-ALK chimeric protein is constitutively expressed from the NPM promoter, leading to the overexpression of the ALK catalytic domain. Many other rearrangements involving the $A L K$ gene have recently been shown to be associated with ALCL, including ALO17-ALK, TRK-fused gene (TFG)-ALK, moesin (MSN)-ALK, Tropomyosin 3 (TPM3)ALK, Tropomyosin 4 (TPM4)-ALK, ATIC-ALK, myosin 9(MYH9)-ALK, CLTC-ALK [15]. Of interest, the chimeric protein seems to behave as neo-antigent leading to the production of autologous antibodies against chimeric protein, suggesting an immune response to the ALK protein [16].

The $\mathrm{t}(2 ; 17)(\mathrm{p} 23 ; \mathrm{q} 23)$ translocation, which generates CLTC-ALK is also found in diffuse large B-cell lymphoma (DLBCL) and represents the most frequent chromosomal rearrangement in this disease. A small portion (0.5-1\%) of DLBCLs display the NPM-ALK fusion protein or other fusion proteins such as Sequestosome 1 (SQSTM1)-ALK and SEC31A-ALK.

Inflammatory myofibroblastic tumors (IMT) were the first solid tumor to be associated with $A L K$ translocation. Approximately $50 \%$ of IMT display clonal rearrangements of $A L K$ gene fused to TPM3 or to TPM4, $[17,18]$ two genes encoding for a non-muscle tropomyosin. Both TPM3-ALK and TPM4-ALK proteins cause constitutive autophosphorylation and activation of ALK [19] with consequent downstream activation of STAT3. Many other fusion proteins are found in IMT, including CLTC-ALK, ATIC-ALK, SEC31A-ALK, RANBP2-ALK, PPFIBP1- ALK, and CARS-ALK.

In 2007, the chromosomal rearrangement involving the ALK and EML4 (echinoderm microtubule-associated protein like 4) genes was identified in about 5\% of NSCLC patients [19]; the rearrangement is frequently observed in relatively younger patients, non- or light smokers, and those with adenocarcinoma histology without other genetic disorders, such as mutations of the epidermal growth factor receptor (EGFR) gene [20, 21]. All 13 fusion variants of EML4-ALK contain exons 2029 of $A L K$, which encode the entire intracellular segment of ALK, and 8 different EML4 exons (2, 6, 13, $14,15,17,18$, and 20). Other ALK fusion proteins have also been described in NSCLC, including KIF5B-ALK, TFG-ALK, KLC1-ALK, PTPN3-ALK, and STRN-ALK with the consequent activation of downstream signalings including Ras/ERK1/2, PI3K/Akt, and JAK/STAT. Importantly, inhibitors of ALK significantly suppressed the growth of BA/F3 cells that express EML4-ALK [22] thus identifing $A L K$ rearrangements as new potential therapeutic targets. Although the proportion of NSCLCs with
EML4- ALK fusion proteins is low (5\%), the absolute number results high as a consequence of the relatively high incidence of NSCLC. Therefore, ALK-rearranged NSCLC cases represent the largest population amenable of therapy with ALK inhibitors than other known ALKrelated cancers combined.

Despite the variety of ALK fusion partners, some common features can be highlighted. Whenever an ALK fusion occurs, it will result in the activation of the ALK protein kinase domain that plays a key role in the tumorigenic process. The partner protein, which is the C-terminal of the fusion protein, controls the protein's behavior, such as expression level and activation. Therefore, these cells uncontrolledly proliferate, survive, differentiate, and migrate, consequently leading to cancer [23].

Indeed, the initiation of transcription of ALK fusion proteins is driven by the regulatory regions of the partner gene; the subcellular localization of the fusion protein is determined by the partner protein, which means that ALK activity can occur in the nucleus and/or in the cytoplasm. The dimerization of ALK fusions occurs through the ALK partner protein and involves transautophosphorylation, and thus activation of the ALK kinase domain.

However, gene fusions are only a part of the genetic alteration affecting ALK gene.

Amplification of the $A L K$ locus and consequent overexpression of ALK protein has been reported in many different types of cancer cell lines and human tumor samples [16, 24] including melanoma, NSCLC, neuroblastoma, glioblastoma, rhabdomyosarcoma, ovarian cancer, breast cancer, astrocytoma, Ewing's sarcoma, and retinoblastoma.

Regardless of amplification, ALK overexpression is widely observed in nearly $100 \%$ of basal cell carcinoma [25] and in more than $50 \%$ of neuroblastomas, with only $10 \%$ of primary neuroblastomas displaying also $A L K$ gene amplification. On the other side, ALK mutation is found in $7 \%$ of sporadic neuroblastomas and $50 \%$ of familial neuroblastomas. Most of the ALK mutations described are located within the kinase domain, and several have been shown to behave oncogenetic in in vitro and in vivo models $[24,26,27] . A L K$ point mutations have been found mainly in neuroblastoma, as well as in NSCLC and ATC (anaplastic thyroid cancer). NSCLC and IMT gateway mutations often occur as secondary mutations in the context of acquired resistance to specific inhibitors, such as crizotinib.

\section{Targeting ALK in cancer}

The presence of ALK fusion proteins and the constitutive ALK tyrosine kinase activity represent a therapeutic target in all malignancies with $A L K$ rearrangement. 


\section{Mechanisms of resistance to ALK inhibitors}

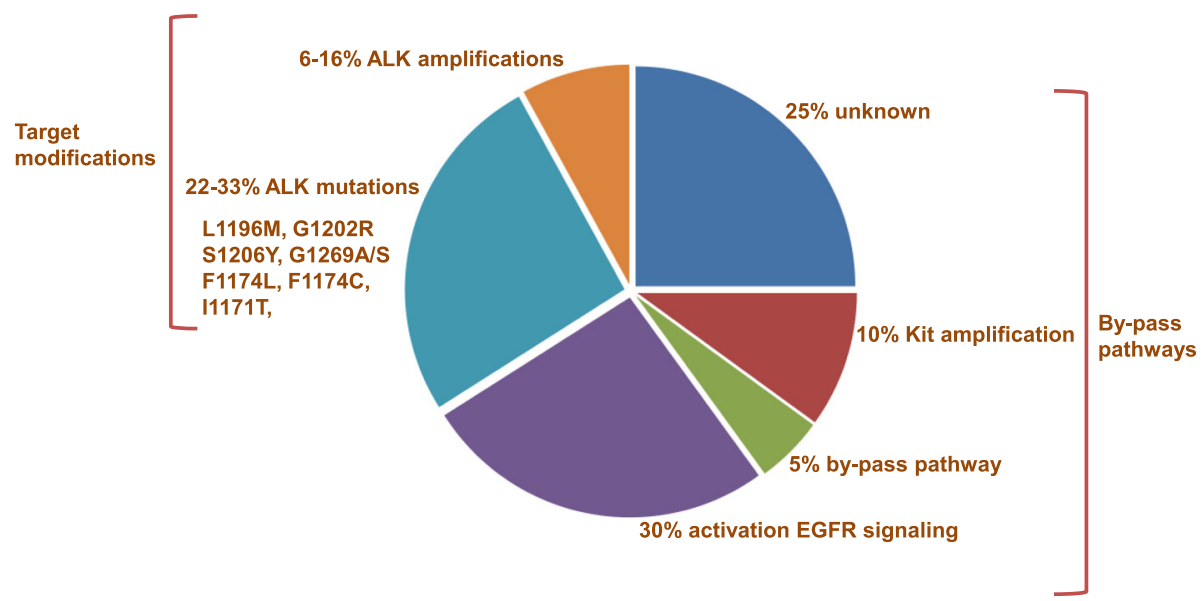

Fig. 3 Mechanisms of resistance to ALK inhibitors. Resistance to ALK inhibitors may be mediated by acquired secondary mutations in the ALK kinase domain (F1174 L, F1174C, L1196 M, I1171T, G1202R, S1206Y, G1269S, and G1269A) or ALK gene amplification indicating the persistance of ALK dependency. Resistance can also be mediated by activation of alternative survival pathways such as the EGFR or the insulin-like growth factor pathways

Further, considering that ALK is not widely expressed in adult tissue, few toxic effects might be expected from treatment aimed at blocking ALK function.

The first ALK inhibitor introduced in the treatment of ALK-dependent NSCLC has been crizotinib, a potent oral small-molecule tyrosine kinase inhibitor of ALK, as well as c-MET and C-ros oncogene 1 (ROS1) kinases. Early phase I studies with crizotinib in ALK-fusionpositive metastatic pre-treated NSCLC patients [28-30] showed an objective response rate (ORR) of $57 \%$.

Two phase III studies, which led to the United State Food and Drug Administration (FDA) approval of crizotinib, further confirmed the superiority of crizotinib on standard chemotherapy as first or second line therapy of ALK-rearranged NSCLC patients [31, 32]. In the PROFILE 1007 study, crizotinib showed ORR of 65\% as compared with $20 \%$ with either pemetrexed or docetaxel in patients who had failed one prior platinum-based regimen [31]. In treatment-naive ALK-positive NSCLC (PROFILE 1014), crizotinib significantly improved progression-free survival (PFS) (median, 10.9 months versus 7 months) and ORR as compared to standard first-line chemotherapy [32] indicating a clear and effective new strategy window for ALK-rearranged patients. Of particular interest, crizotinib was associated with disease control in patients with brain metastasis [33].

Similarly, crizotinib also showed therapeutic response in ALK-fusion-positive IMT patients [34] and pediatric patients with anaplastic large cell lymphoma and IMT [35].
However, some patients do not respond to crizotinib or even after an initial response, lasting a median of 12 13 months, acquired resistance occurs.

Several resistance mechanisms have been described, mostly defined as ALK-dependent or non ALKdependent according to the maintenance or not of the oncogenetic role of ALK signaling. Acquired secondary mutations in the ALK kinase domain (F1174 L, F1174C, L1196 M, I1171T, G1202R, S1206Y, G1269S, and G1269A) or $A L K$ gene amplification [36-40] are known to be associated with resistance. Resistance can also be mediated by activation of alternative ALK-independent survival pathways such as the EGFR or the insulin-like growth factor pathways or the RAS/SRC and AKT/ mTOR signalings [30-43] (Fig. 3).

The most common site of relapse after crizotinib treatment is the central nervous system (CNS) as a consequence of the to the $\mathrm{P}$-glycoprotein (P-gp)-mediated efflux that is responsible for the poor accumulation of the drug in this site.

As previously mentioned, although the acquisition of resistance, most tumors progressing on crizotinib continue to depend on ALK signaling and are sensitive to more potent, structurally distinct, second-generation ALK inhibitors, such as ceritinib, alectinib, brigatinib, and lorlatinib.

In preclinical studies, ceritinib efficiently inhibited several $A L K$ secondary mutations developed after crizotinib therapy [44]. In a phase I study, ceritinib was administered to $114 A L K$-rearranged, crizotinib-naïve and 
-resistant NSCLC patients [45] achieving an ORR of $58 \%$, and demonstrating activity also in those patients with $A L K$ gene amplification or mutations (L1196 M, S1206Y) developed after crizotinib therapy. Ceritinib gained approval as the second-line treatment after crizotinib, thus expanding the tools of effective therapeutic options for ALK-positive NSCLC. The approval of ceritinib was based on the positive data in the ASCEND-2 and ASCEND-3 studies, in which an increased ORR was found in both crizotinib-naive and -resistant patients $[46,47]$. In the ASCEND-4 study, progression-free survival (PFS) was 16.6 months compared to 8.1 months in the platinum-based chemotherapy arm [48].

Alectinib is a second generation potent and selective anti-ALK therapy able to bypass resistance to crizotinib exhibiting in vitro and in vivo activity in several $A L K$-resistant mutations, including L1196 M, F1174 L, R1275Q, and C1156Y [49, 50].

In 2016, alectinib gained the FDA and European Medicines Agency (EMA) approval as a second-line therapy in $A L K$-rearranged NSCLC patients treated with crizotinib [51].

Two phase I-II studies showed that alectinib was well tolerated. The first study (Japanese Phase I-II study (AF-0001JP), conducted in ALK inhibitor-naïve patients with $A L K$-rearranged NSCLC showed objective response of $93.5 \%$ [52]. Treatment was continued reaching a 3year PFS of $62 \%$ (95\% confidence interval [CI], 45\%$75 \%$ ) and a 3 -year overall survival (OS) of $78 \%$. Importantly of the 14 patients with brain metastases at baseline, six ones remained without progression [53]. The second study tested the efficacy of alectinib in patients with crizotinib-resistant $A L K$-rearranged NSCLC and showed objective response of 55\% [54].

Then, two phase II studies (NP28761 and NP28673) in $A L K$-positive, crizotinib-resistant patients showed similar results with an ORR of $48 \%$ and $50 \%$ respectively and a median PFS of 8.1 months (95\% CI, 6.2-12.6 months) and 8.9 months (95\% CI, 5.6-11.3 months) respectively $[55,56]$. Both studies also demonstrated the efficacy of alectinib against CNS metastasis. This can be explained by the increased penetration in the CNS, as alectinib is not transported by P-gp-mediated transport and thus reaches a higher CNS- to-plasma ratio than crizotinib [57].

The role of alectinib in the first line therapy of $A L K$ positive NSCLC patients has been explored in two phase III trials. The J-ALEX trial compared the efficacy and safety of alectinib versus crizotinib in japanese $A L K$ positive advanced or recurrent NSCLC patients with no prior ALK inhibition therapy. Patients receiving alectinib had not yet reached the median PFS, while patients receiving crizotinib showed a median PFS of 10.2 months. Safety profile was in favour of alectinib with grade 3-4 toxicities less frequent in the alectinib arm (27\%) compared to the crizotinib arm (52\%) [58].

In addition to the J-ALEX trial, the results from the ALEX phase III randomized clinical trial conducted in non-asian $A L K$-positive untreated patients comparing alectinib with crizotinib, have been recently presented. The authors reported similar results regarding the superiority of alectinib versus crizotinib: lower chance of progression ( $41 \%$ vs $68 \%$ ), higher 12-month event-free survival rate $(68.4 \%$ vs $48.7 \%)$, lower rate of CNS progression ( $12 \%$ vs $45 \%)$, higher response rate $(82.9 \%$ vs $75.5 \%)$, and less adverse events ( $41 \%$ vs $50 \%$ ) [59]. These results strongly support the role of alectinib as a firstline treatment instead of crizotinib.

These studies suggest that crizotinib-resistant tumors keep dependency on ALK signaling, and this is extremely interesting since both ceritinib and alectinib are able to inhibit $A L K$-positive NSCLC mutants harboring different resistance mutations [60].

Other ALK inhibitors are also in development such as entrectinib, lorlatinib and brigatinib, the latter received regulatory approval recently [61]. Among the various investigational drugs, entrectinib, (a multitarget drug, previously known as RXDX-101 and NMS-E628) has demonstrated a promising antitumor activity. It is a selective inhibitor of ALK, of the TPM A, B and C (encoded by the NTRK1, 2, and 3 genes) and of ROS1, with a 36-fold greater potency than crizotinib [62, 63]. Two phase I trials of entrectinib ((ALKA-372-001 and STARTRK-1) had evaluated its safety profile, showing that entrectinib was well tolerated, with the majority of adverse event being reversible and grades $1-2$. Confirmed responses were achieved in five different tumoral histologies in both adult and pediatric patients, including NSCLC, colorectal cancer, mammary analog secretory carcinoma, melanoma, and renal cell carcinoma, from 4 weeks after starting therapy and lasted until two years. Responses were observed in 19/24 (79\%) patients with extracranial solid tumors and in two patients with brain tumors, thus confirming that entrectinib is highly CNSpenetrant. In particular, one patient with NTRK rearranged astrocytoma obtained tumor shrinkage and one patient with SQSTM1-NTRK1-rearranged lung cancer with multiple brain metastasis, not underwent to radiotherapy, achieved a complete CNS response with entrectinib [63]. Considering the high variability of study population, the secondary endpoints median PFS was 8.3 months in ALK positive patients, while it was not reached in NTRK and ROS1 rearranged patients (3,6 and 6,5 months, respectively, as minimum value of $\mathrm{CI}$, confidence interval, 95\% to not reached) and median OS has not been reached in all subgroups, with $89.4 \%$ of patients alive at one year, after a median duration of follow up of 15 months [63]. These results of the phase I study 
of entrectinib in patients with NTRK/ROS1/ALK gene fusions have led to the initiation of an open-label, multicenter, global, phase II basket study (STARTRK-2, NCT02568267) to test the use of entrectinib in patients having tumors with these gene rearrangements, still ongoing.

Recently, data of phase I trial of lorlatanib in $A L K$ or ROS1 rearrangement positive patients was published [64]. Lorlatanib showed a very good tolerability profile with only one dose-limiting toxicity occurred at $200 \mathrm{mg}$ and recommended phase II dose fixed to $100 \mathrm{mg}$ once daily. Among $A L K$ positive patients enrolled in this trial, 19/41 (46\%) showed objective response, of which 11/19 (58\%) had been treated previously with two or more lines of anti-ALK targeted agents, including patients with brain progression desease [64].

The actual stage of clinical development of ALK inhibitors and their specific targets are indicated in Table 1.

\section{Conclusions}

So far, the ideal start and sequence of ALK inhibitors still need to be defined. The choice between different ALK inhibitors may depend on the $A L K$ resistance mutations occurring during treatments. Each ALK inhibitor indeed exhibits its own molecular response, and continuous surveillance on resistance mutations is crucial for an effective treatment strategy. Depending on the type of crizotinib- resistant mutations, patients can now be offered the choice between two potent and effective ALK inhibitors, and other even more potent inhibitors are under clinical investigation, improving longterm treatment strategies $[56,65]$.

It seems evident from the recent success of ceritinib and the fast-track FDA approval of alectinib that genomic profiling of NSCLC tumors is necessary to personalize the treatment of $A L K$-positive lung cancer patients [65]. Especially after progression on secondgeneration ALK inhibitors, different mutations may occur. Entrectinib may have a role in this setting of patients; even if patients who had received crizotinib or other ALK-targeted drugs ceritinib or alectinib did not benefit from treatment in terms of responses in phase I trials with entrectinib, further investigation are needed to clarify the activity of entrectinib in ALK pre-treated patients, considering that it is active against resistance mutations such as the ALK L1196 M mutation, that can onset under crizotinib therapy, and that it is very CNSpenetrant [63]. Ongoing phase II trial of entrectinib is enrolling previously treated ALK positive NSCLC patients with only CNS progression disease.

Table 1 Targets and phase of clinical development of ALK inhibitors

\begin{tabular}{|c|c|c|c|}
\hline Drug & Targets & Phase of clinical development & References \\
\hline Crizotinib & $\begin{array}{l}\text { ALK } \\
\text { C-MET } \\
\text { ROS1 }\end{array}$ & $\begin{array}{l}\text { Indication worldwide for therapy } \\
\text { of NSCLC harbouring ALK gene } \\
\text { rearrangement in first and second line }\end{array}$ & $\begin{array}{l}\text { - Shaw AT, et al. NEJM } 2013 \text { [32] } \\
\text { - Solomon BJ, et al. NEJM } 2014 \text { [33] }\end{array}$ \\
\hline Alectinib & $\begin{array}{l}\text { ALK, including } \\
\text { ALK secondary } \\
\text { mutationsRET }\end{array}$ & $\begin{array}{l}\text { - Approval from FDA (December 2015) } \\
\text { and EMA (February 2017) in second line } \\
\text { therapy of NSCLC harbouring ALK gene } \\
\text { after progression to crizotinib } \\
\text { - FDA granted fast approval in first line } \\
\text { setting based on results of phase II and } \\
\text { III clinical trials }\end{array}$ & $\begin{array}{l}\text { - Larkins E, et al. CCR } 2016 \text { [52] } \\
\text { - Shaw AT, et al. Lancet Oncol } 2016 \text { [56] } \\
\text { - Hida T, et al. Lancet } 2017 \text { [59] } \\
\text { - Peters S, et al. NEJM } 2017 \text { [60] }\end{array}$ \\
\hline Ceritinib & $\begin{array}{l}\text { ALK, including } \\
\text { ALK secondary } \\
\text { mutations } \\
\text { IGF-1R } \\
\text { ROS1 } \\
\text { STK22D }\end{array}$ & $\begin{array}{l}\text { - Recent fast approval from FDA in } \\
\text { second line therapy of NSCLC } \\
\text { harbouring ALK gene after } \\
\text { progression to crizotinib } \\
\text { (May 2017) based on results } \\
\text { of phase II clinical trials }\end{array}$ & $\begin{array}{l}\text { - Crinò L, et al. JCO } 2016 \text { [48] } \\
\text { - Shaw AT, et al. JTO } 2016 \text { [47] }\end{array}$ \\
\hline Brigatinib & $\begin{array}{l}\text { ALK, including } \\
\text { ALK secondary } \\
\text { mutations } \\
\text { ROS1 } \\
\text { EGFR } \\
\text { NTRK1 }\end{array}$ & $\begin{array}{l}\text { - Recent fast approval from FDA } \\
\text { in second line therapy of NSCLC } \\
\text { harbouring ALK gene after } \\
\text { progression to crizotinib (April 2017) } \\
\text { based on results of phase II clinical trials }\end{array}$ & • Markham A, et al. Drugs 2017 [61] \\
\hline Lorlatanib & $\begin{array}{l}\text { ALK and ROS1, } \\
\text { including all } \\
\text { known their } \\
\text { mutant forms }\end{array}$ & $\begin{array}{l}\text { Ongoing phase III trials in NSCLC first } \\
\text { line versus crizotinib }\end{array}$ & - ClinicalTrials.gov, NCT03052608 \\
\hline Entrectinib & $\begin{array}{l}\text { ALK, Including } \\
\text { ALK secondary } \\
\text { mutations } \\
\text { NTRK1, 2, and } 3 \\
\text { ROS1 }\end{array}$ & $\begin{array}{l}\text { Ongoing phase II basket trial } \\
\text { STARTRK-2 (NCT02568267) }\end{array}$ & • Drilon A, et al. Cancer Discovery 2017 [63] \\
\hline
\end{tabular}


In addition, possibility of rechallenging therapies cannot be excluded: in a recent report, Shaw et al. showed an interesting resensitization of a $A L K$-rearranged NSCLC patient being retreated with crizotinib. The patient, indeed, after acquisition of resistance to first-line crizotinib was treated with chemotherapy and then with second-generation ALK inhibitor ceritinib. As resistance to ceritinib occurred, lorlatinib, the third-generation ALK inhibitor, was administered. Once the patient became lorlatinib resistant and developed an L1198F mutation in ALK the patient was subsequently re-treated with crizotinib obtaining again disease remission [66]. Data from phase I trial of lorlatanib suggest a potential role of this drug after resistance to various anti-ALK agents, in $A L K$ positive patients, including the subset of patients with brain metastasis [64]. Ongoing phase III trial of lorlatanib will clarify its activity in first line of therapy for $A L K$ positive patients (NCT03052608).

In addition to keep ALK blocked with specific inhibitors, there are pharmacological strategies that allow for its indirect targeting. Specifically, inhibitiong heat-shock proteins (HSP), namely HSP90, a chaperone protein that stabilizes a wide variety of proteins, including ALK, has shown some preclinical efficacy in crizotinib-resistant $A L K$ fusions (EML4-ALK and NPM1-ALK), including secondary resistant mutants in lung cancer models [67]. In addition, several drug combinations, including ALK inhibitors and other receptor tyrosine kinase inhibitor, such as Insulin-like growth factor 1 receptor-1 (IGF1R) [68], Mitogen-activated protein kinase kinase (MEK) [69-71] and HSP90 [67] inhibitors, are being explored in preclinical/clinical studies.

Immune-based therapeutic strategies are under investigation in ALK-positive ALCL. The evidence of ALK fusion protein as good immunogenic stimulus [16] is leading to several strategies for anti-ALK immune-based treatments of chemotherapy-resistant ALCL. Similarly, as recent preclinical data indicate, the immune checkpoint proteins are induced in $A L K$-positive NSCLC tumors [72], thus, combination therapies of checkpoint (PD-1/PD-L1, CTLA-4) and ALK inhibitors are being explored in the clinical setting for $A L K$-positive NSCLC patients (NCT02393625, NCT01998126).

Chemotherapy also remains a viable option in NSCLC patients with ALK translocations where pemetrexedbased chemotherapy may be more effective than other non-pemetrexed combinations [73].

\footnotetext{
Abbreviations

aa: Aminoacids; ALCL: Anaplastic large cell lymphoma; ALK: Anaplastic lymphoma kinase; ATC: Anaplastic thyroid cancer; Cl: Confidence Interval; CNS: Central nervous system; CR: Complete response; DLBCL: Diffuse large Bcell lymphoma; EGFR: Epidermal growth factor receptor; EMA: European Medicines Agency; EML4: echinoderm microtubule-associated protein like 4; FDA: Food and Drug Administration; HSP: Heat-shock proteins; IGF1R: Insulinlike growth factor 1 receptor-1; IMT: Inflammatory myofibroblastic tumors;
}

JAK: Janus kinase; LTK: Leukocyte tyrosine kinase; MAPK: Mitogen-activated protein kinase; MEK: Mitogen-activated protein kinase kinase; MSN: Moesin; mTOR: Mammalian target of rapamycin; MYH9: Myosin 9; NPM: Nucleolar phosphoprotein B23 numatrin; NSCLC: Non-small cell lung cancer; ORR: Objective response rate; OS: Overall survival; PFS: Progression-free survival; PI3K: Phosphoinositide 3-kinase; PR: Partial response; PTPRB/ PTPRZ1: Protein tyrosine phosphatase beta and zeta complex; ROS1: C-ros oncogene 1; RTK: Receptor tyrosine kinase; SD: Stable disease; SQSTM1: Sequestosome 1; STAT: Signal transducer and activator of transcription; TFG: TRK-fused gene; TPM3: Tropomyosin 3;

TPM4: Tropomyosin 4

\section{Funding}

This work has been supported by Associazione Italiana Per La Ricerca Sul Cancro (AIRC)-Project MFAG 2013-N.14392.

\section{Authors' contributions}

CDC and FM conducted literature researches and wrote the paper. GV and $\mathrm{RDL}$ conducted literature researches and made the figures and Table. MF, EM and $T T$ conducted literature researches. FC reviewed the paper. All authors read and approved the final manuscript.

\section{Competing interests}

Authors declare that have no financial relationships with any organizations that might have an interest in the submitted work in the previous three years.

\section{Publisher's Note}

Springer Nature remains neutral with regard to jurisdictional claims in published maps and institutional affiliations.

Received: 31 October 2017 Accepted: 1 February 2018

Published online: 19 February 2018

\section{References}

1. Lemmon MA, Schlessinger J. Cell signaling by receptor tyrosine kinases. Cell. 2010;141:1117-34.

2. Morris SW, Naeve C, Mathew $P$, James PL, Kirstein MN, Cui $X$, et al. ALK, the chromosome 2 gene locus altered by the $t(2 ; 5)$ in non-Hodgkin's lymphoma, encodes a novel neural receptor tyrosine kinase that is highly related to leukocyte tyrosine kinase (LTK). Oncogene. 1997;14:2175-88.

3. Pulford K, Lamant L, Morris SW, Butler LH, Wood KM, Stroud D, et al. Detection of anaplastic lymphoma kinase (ALK) and nucleolar pro- tein nucleophosmin (NPM)-ALK proteins in normal and neoplastic cells with the monoclonal antibody ALK1. Blood. 1997;89:1394-404.

4. Iwahara T, Fujimoto J, Wen D, Cupples R, Bucay N, Arakawa T, et al. Molecular characterization of ALK, a receptor tyrosine kinase expressed specifically in the nervous system. Oncogene. 1997;14:439-49.

5. Roskoski R Jr. Anaplastic lymphoma kinase (ALK): structure, oncogenic activation, and pharmacological inhibition. Pharmacol Res. 2013;68:68-94.

6. Lee CC, Jia Y, Li N, Sun X, Ng K, Ambing E, et al. Crystal structure of the ALK (anaplastic lymphoma kinase) catalytic domain. Biochem J. 2010:430:425-37.

7. Bossi RT, Saccardo MB, Ardini E, Menichincheri M, Rusconi L, Magnaghi P, et al. Crystal structures of anaplastic lymphoma kinase in complex with ATP competitive inhibitors. Biochemistry. 2010;49:6813-25.

8. Perez-Pinera P, Zhang W, Chang Y, Vega JA, Deuel TF. Anaplastic lymphoma kinase is acti- vated through the pleiotrophin/receptor protein- tyrosine phosphatase beta/zeta signaling pathway: an alternative mechanism of receptor tyrosine kinase activation. J Biol Chem. 2007;282:28683-90.

9. Stoica GE, Kuo A, Powers C, Bowden ET, Sale EB, Riegel AT, et al. Midkine binds to anaplastic lymphoma kinase (ALK) and acts as a growth factor for different cell types. J Biol Chem. 2002;277:35990-8.

10. Palmer RH, Vernersson E, Grabbe C, Hallberg B. Anaplastic lymphoma kinase: signalling in development and disease. Biochem J. 2009:420:345-61.

11. Morris SW, Kirstein MN, Valentine MB, Dittmer K, Shapiro DN, Look AT, et al. Fusion of a kinase gene, ALK, to a nucleolar protein gene, NPM, in nonHodgkin's lymphoma. Science. 1995;267:316-7.

12. Shiota M, Fujimoto J, Semba T, Satoh H, Yamamoto T, Hyperphosphorylation MS. Of a novel 80 kDa protein-tyrosine kinase similar to Ltk in a human Ki-1 lymphoma cell line, AMS3. Oncogene. 1994;9:1567-74. 
13. Soda M, Choi YL, Enomoto M, Takada S, Yamashita Y, Ishikawa S, et al. Identification of the transforming EML4-ALK fusion gene in non-small-cell lung cancer. Nature. 2007;448:561-6.

14. Bitter MA, Franklin WA, Larson RA, McKeithan TW, Rubin CM, Le Beau MM, et al. Morphology in Ki-1(CD30)-positive non- Hodgkin's lymphoma is correlated with clinical fea- tures and the presence of a unique chromosomal abnormality, t(2;5)(p23;q35). Am J Surg Pathol. 1990;14:305-16.

15. Grisendi S, Mecucci C, Falini B, Pandolfi PP. Nucleophosmin and cancer. Nat Rev Cancer. 2006;6:493-505.

16. Boi M, Zucca E, Inghirami G, Bertoni F. Advances in understanding the pathogenesis of systemic anaplastic large cell lymphomas. Br J Haematol. 2015; 168:771-83.

17. Pulford K, Falini B, Banham AH, Codrington D, Roberton $\mathrm{H}$, Hatton $\mathrm{C}$, et al Immune response to the ALK oncogenic tyrosine kinase in patients with anaplastic large-cell lymphoma. Blood. 2000:96:1605-7.

18. Coffin CM, Patel A, Perkins S, Elenitoba-Johnson KS, Perlman E, Griffin CA. ALK1 and p80 expression and chromosomal rearrangements involving 2p23 in inflammatory myofibroblastic tumor. Mod Pathol. 2001;14:569-76.

19. Griffin CA, Hawkins AL, Dvorak C, Henkle C, Ellingham T, Recurrent PEJ. Involvement of 2p23 in inflammatory myofibroblastic tumors. Cancer Res. 1999:59:2776-80.

20. Chiarle R, Martinengo C, Mastini C, Ambrogio C, D'Escamard V, Forni G, et al. The anaplastic lymphoma kinase is an effective oncoantigen for lymphoma vaccination. Nat Med. 2008;14:676-80.

21. Toyokawa G, Seto T. Anaplastic lymphoma kinase rearrangement in lung cancer: its biological and clini- cal significance. Respir Investig. 2014;52:330-8.

22. Guérin A, Sasane M, Zhang J, Macalalad AR, Galebach P, Jarvis J, et al. ALK rearrangement testing and treatment patterns for patients with ALK-positive non-small cell lung cancer. Cancer Epidemiol. 2015;39:307-12.

23. Katayama R, Khan TM, Benes C, Lifshits E, Ebi H, Rivera VM, et al. Therapeutic strategies to overcome crizotinib resistance in non-small cell lung cancers harboring the fusion oncogene EML4-ALK. Proc Natl Acad Sci U S A. 2011 108:7535-40.

24. Duyster J, Bai RY, Morris SW. Translocation involving anaplastic lymphoma kinase (ALK). Oncogene. 2001;20:5623-37.

25. Lamant L, Pulford K, Bischof D, Morris SW, Mason DY, Delsol G, et al. Expression of the ALK tyrosine kinase gene in neuroblastoma. Am J Pathol. 2000;156:1711-21.

26. Shackelford RE, Vora M, Mayhall K, Cotelingam J. ALK-rearrangements and testing methods in non- small cell lung cancer: a review. Genes Cancer. 2014;5:1-14.

27. Chen Y, Takita J, Choi YL, Kato M, Ohira M, Sanada M, et al. Oncogenic mutations of ALK kinase in neuroblastoma. Nature. 2008;455:971-4.

28. Janoueix-Lerosey I, Lequin D, Brugieres L, Ribeiro A, de Pontual L, Combaret $V$, et al. Somatic and germline activating mutations of the ALK kinase receptor in neuroblastoma. Nature. 2008;455:967-70.

29. Kwak EL, Bang YJ, Camidge DR, Shaw AT, Solomon B, Maki RG, et al. Anaplastic lymphoma kinase inhibition in non-small-cell lung cancer. N Engl J Med. 2010:363:1693-703.

30. Shaw AT, Yeap BY, Solomon BJ, Riely GJ, Gainor J, Engelman JA, et al. Effect of crizotinib on overall survival in patients with advanced non-small-cell lung cancer harbouring ALK gene rearrangement: a retrospective analysis. Lancet Oncol. 2011:12:1004-12.

31. Camidge DR, Bang YJ, Kwak EL, lafrate AJ, Varella-Garcia M, Fox SB, et al. Activity and safety of crizotinib in patients with ALK-positive nonsmall-cell lung cancer: updated results from a phase I study. Lancet Oncol. 2012;13:1011-9.

32. Shaw AT, Kim DW, Nakagawa K, Seto T, Crino L, Ahn MJ, et al. Crizotinib versus chemotherapy in advanced ALK-positive lung cancer. N Engl J Med. 2013:368:2385-94

33. Solomon BJ, Mok T, Kim DW, Wu YL, Nakagawa K, Mekhail T, et al. First-line crizotinib versus chemotherapy in ALK-positive lung cancer. N Engl J Med. 2014;371:2167-77.

34. Costa DB, Shaw AT, Ou SH, Solomon BJ, Riely GJ, Ahn MJ, et al. Clinical experience with crizotinib in patients with advanced ALK-rearranged nonsmall-cell lung cancer and brain metastases. J Clin Oncol. 2015;33:1881-8.

35. Butrynski JE, D'Adamo DR, Hornick JL, Dal Cin P, Antonescu CR, Jhanwar SC, et al. Crizotinib in ALK-rearranged inflammatory myofibroblastic tumor. $\mathrm{N}$ Engl J Med. 2010;363:1727-33.

36. Mosse YP, Lim MS, Voss SD, Wilner K, Ruffner K, Laliberte J, et al. Safety and activity of crizotinib for paediatric patients with refractory solid tumours or anaplastic large-cell lymphoma: a Children's oncology group phase I consortium study. Lancet Oncol. 2013;14:472-80.

37. Choi YL, Soda M, Yamashita Y, Ueno T, Takashima J, Nakajima T, et al. EML4ALK mutations in lung cancer that confer resistance to ALK inhibitors. N Engl J Med. 2010;363:1734-9.

38. Sasaki T, Okuda K, Zheng W, Butrynski J, Capelletti M, Wang L, et al. The neuroblastoma-associated F1174L ALK mutation causes resistance to an ALK kinase inhibitor in ALK-translocated cancers. Cancer Res. 2010;70:10038-43.

39. Heuckmann JM, Holzel M, Sos ML, Heynck S, Balke-Want H, Koker M, et al. ALK mutations conferring differential resistance to structurally diverse ALK inhibitors. Clin Cancer Res. 2011;17:7394-401.

40. Doebele RC, Pilling AB, Aisner DL, Kutateladze TG, Le AT, Weickhardt AJ, et al. Mechanisms of resistance to crizotinib in patients with ALK gene rearranged non-small cell lung cancer. Clin Cancer Res. 2012;18:1472-82.

41. Katayama R, Shaw AT, Khan TM, Mino-Kenudson M, Solomon BJ, Halmos B, et al. Mechanisms of acquired crizotinib resistance in ALK-rearranged lung cancers. Sci Transl Med. 2012:4:117-20.

42. Scarborough HA, Bunn PA Jr, DeGregori J. Personalized one-two punches for lung cancer. Cell Res. 2015;25:269-70.

43. Ji C, Zhang L, Cheng Y, Patel R, Wu H, Zhang Y, et al. Induction of autophagy contributes to crizotinib resistance in ALK-positive lung cancer. Cancer Biol Ther. 2014;15:570-7.

44. Mengoli MC, Barbieri F, Bertolini F, Tiseo M, Rossi G. K-RAS mutations indicating primary resistance to crizotinib in ALK-rearranged adenocarcinomas of the lung: report of two cases and review of the literature. Lung Cancer. 2016;93:55-8.

45. Friboulet L, Li N, Katayama R, Lee CC, Gainor JF, Crystal AS, et al. The ALK inhibitor ceritinib overcomes crizotinib resistance in non-small cell lung cancer. Cancer Discov. 2014;4:662-73.

46. Shaw AT, Kim DW, Mehra R, Tan DS, Felip E, Chow LQ, et al. Ceritinib in ALK-rearranged non-small-cell lung cancer. N Engl J Med. 2014;370:1189-97.

47. Shaw AT, Spigel DR, Tan DS, Kim DW, Mehra R, Orlov S, et al. MINI01.01: whole body and intracranial efficacy of ceritinib in ALK-inhibitor naive patients with ALK NSCLC and brain metastases: results of ASCEND 1 and 3: topic: medical oncology. J Thorac Oncol. 2016;11:S256

48. Crino L, Ahn MJ, De Marinis F, Groen HJ, Wakelee H, Hida T, et al. Multicenter phase II study of whole-body and intracranial activity with ceritinib in patients with ALK-rearranged non-small-cell lung cancer previously treated with chemotherapy and crizotinib: results from ASCEND2. J Clin Oncol. 2016;34:2866-73.

49. Soria JC, Tan DS, Chiari R, Wu YL, Paz-Ares L, Wolf J, et al. First-line ceritinib versus platinum- based chemotherapy in advanced ALK-rearranged nonsmall-cell lung cancer (ASCEND-4): a randomised, open-label, phase III study. Lancet. 2017;389:917-29.

50. Sakamoto H, Tsukaguchi T, Hiroshima S, Kodama T, Kobayashi T, Fukami TA, et al. CH5424802, a selective ALK inhibitor capable of blocking the resistant gatekeeper mutant. Cancer Cell. 2011:19:679-90.

51. Kodama T, Tsukaguchi T, Yoshida M, Kondoh O, Sakamoto H. Selective ALK inhibitor alectinib with potent antitumor activity in models of crizotinib resistance. Cancer Lett. 2014;351:215-21.

52. Larkins $\mathrm{E}$, Blumenthal $\mathrm{GM}$, Chen $\mathrm{H}$, He K, Agarwal R, Gieser $\mathrm{G}$, et al. FDA approval: alectinib for the treatment of metastatic, ALK-positive non-small cell lung cancer following crizotinib. Clin Cancer Res. 2016;22:5171-6.

53. Seto T, Kiura K, Nishio M, Nakagawa K, Maemondo M, Inoue A, et al. CH5424802 (RO5424802) for patients with ALK-rearranged advanced nonsmall-cell lung cancer (AF-001.JP study): a single-arm, open-label, phase 1-2 study. Lancet Oncol. 2013;14:590-8.

54. Tamura T, Kiura K, Seto T, Nakagawa K, Maemondo M, Inoue A, et al. Threeyear follow-up of an alectinib phase I/II study in ALK-positive non-small-cell lung cancer: AF-001.JP. J Clin Oncol. 2017;35:1515-21.

55. Gadgeel SM, Gandhi L, Riely GJ, Chiappori AA, West HL, Azada MC, et al. Safety and activity of alectinib against systemic disease and brain metastases in patients with crizotinib-resistant ALK-rearranged non-small-cell lung cancer (AF-002JG): results from the dose-finding portion of a phase 1/ 2 study. Lancet Oncol. 2014;15:1119-28.

56. Shaw AT, Gandhi L, Gadgeel S, Riely GJ, Cetnar J, West H, et al. Alectinib in ALK-positive, crizotinib-resistant, non-small-cell lung cancer: a single-group, multi- centre, phase II trial. Lancet Oncol. 2016:17:234-42.

57. Ou SH, Ahn JS, De Petris L, Govindan R, Yang JC, Hughes B, et al. Alectinib in crizotinib-refractory ALK-rearranged non-small-cell lung cancer: a phase II global study. J Clin Oncol. 2016;34:661-8. 
58. Kodama T, Hasegawa M, Takanashi K, Sakurai Y, Kondoh O, Sakamoto H. Antitumor activity of the selective ALK inhibitor alectinib in models of intracranial metastases. Cancer Chemother Pharmacol. 2014;74:1023-8.

59. Hida T, Nokihara H, Kondo M, Kim YH, Azuma K, Seto T, et al. Alectinib versus crizotinib in patients with ALK-positive non-small-cell lung cancer (J-ALEX): an open-label, randomised phase III trial. Lancet. 2017;390:29-39.

60. Peters S, Camidge DR, Shaw AT, Gadgeel S, Ahn JS, Kim DW, et al. Alectinib versus crizotinib in untreated ALK-positive non-small-cell lung cancer. N Engl J Med. 2017;377:829-38.

61. Markham A. Brigatinib: first global approval. Drugs. 2017;77:1131-5.

62. Menichincheri M, Ardini E, Magnaghi P, Avanzi N, Banfi P, Bossi R, et al. Discovery of Entrectinib: a new 3-Aminoindazole as a potent anaplastic lymphoma kinase (ALK), c-ROS oncogene 1 kinase (ROS1), and pantropomyosin receptor kinases (pan-TRKs) inhibitor. J Med Chem. 2016;59: 3392-408.

63. Drilon A, Siena S, Ou SI, Patel M, Ahn MJ, Lee J, et al. Safety and antitumor activity of the multitargeted pan-TRK, ROS1, and ALK inhibitor Entrectinib: combined results from two phase I trials (ALKA-372-001 and STARTRK-1). Cancer Discov. 2017;7:400-9.

64. Shaw AT, Felip E, Bauer TM, Besse B, Navarro A, Postel-Vinay S, et al. Lorlatinib in non-small-cell lung cancer with ALK or ROS1 rearrangement: an international, multicentre, open-label, single-arm first-in-man phase 1 trial. Lancet Oncol. 2017;18:1590-9.

65. Muller IB, De Langen AJ, Honeywell RJ, Giovannetti E, Peters GJ. Overcoming crizotinib resistance in ALK-rearranged NSCLC with the second-generation ALK-inhibitor ceritinib. Expert Rev Anticancer Ther. 2016;16:147-57.

66. Shaw AT, Friboulet L, Leshchiner I, Gainor JF, Bergqvist S, Brooun A, et al. Resensitization to crizotinib by the lorlatinib ALK resistance mutation L1198F. N Engl J Med. 2016;374:54-61.

67. Sang J, Acquaviva J, Friedland JC, Smith DL, Sequeira M, Zhang C, et al Targeted inhibition of the molecular chaperone Hsp90 overcomes ALK inhibitor resistance in non-small cell lung cancer. Cancer Discov. 2013;3: 430-43.

68. Lovly CM, McDonald NT, Chen H, Ortiz-Cuaran S, Heukamp LC, Yan Y, et al. Rationale for co-targeting IGF-1R and ALK in ALK fusion-positive lung cancer. Nat Med. 2014;20:1027-34.

69. Tanizaki J, Okamoto I, Takezawa K, Sakai K, Azuma K, Kuwata K, et al. Combined effect of ALK and MEK inhibitors in EML4-ALK-positive non-smallcell lung cancer cells. Br J Cancer. 2012;106:763-7.

70. Crystal AS, Shaw AT, Sequist LV, Friboulet L, Niederst MJ, Lockerman EL, et al. Patient-derived models of acquired resistance can identify effective drug combinations for cancer. Science. 2014;346:1480-6.

71. Hrustanovic G, Olivas V, Pazarentzos E, Tulpule A, Asthana S, Blakely CM, et al. RAS-MAPK dependence underlies a rational polytherapy strategy in EML4-ALK-positive lung cancer. Nat Med. 2015;21:1038-47.

72. Ota K, Azuma K, Kawahara A, Hattori S, Iwama E, Tanizaki J, et al. Induction of PD-L1 expression by the EML4-ALK oncoprotein and downstream signaling pathways in non-small cell lung cancer. Clin Cancer Res. 2015;21:4014-21.

73. Camidge DR, Kono SA, Lu X, Okuyama S, Baron AE, Oton AB, et al. Anaplastic lymphoma kinase gene rearrangements in non-small cell lung cancer are associated with prolonged progression-free survival on pemetrexed. J Thorac Oncol. 2011;6:774-80.

\section{Submit your next manuscript to BioMed Central and we will help you at every step:}

- We accept pre-submission inquiries

- Our selector tool helps you to find the most relevant journal

- We provide round the clock customer support

- Convenient online submission

- Thorough peer review

- Inclusion in PubMed and all major indexing services

- Maximum visibility for your research

Submit your manuscript at www.biomedcentral.com/submit 